\title{
Active Specific Immunotherapy in Patients with Melanoma
}

\author{
A Clinical Trial with Mouse Antiidiotypic Monoclonal Antibodies Elicited \\ with Syngeneic Anti-High-Molecular-Weight-Melanoma-Associated \\ Antigen Monoclonal Antibodies
}

\author{
A. Mittelman, ${ }^{*}$ Z. J. Chen, ${ }^{\ddagger}$ T. Kageshita, ${ }^{\ddagger}$ H. Yang, ${ }^{\ddagger}$ M. Yamada, ${ }^{\ddagger}$ P. Baskind, ${ }^{*}$ N. Goldberg, ${ }^{5}$ \\ C. Puccio, ${ }^{*}$ T. Ahmed, ${ }^{\star} Z$. Arlin, ${ }^{*}$ and S. Ferrone ${ }^{\ddagger}$ \\ ${ }^{*}$ Departments of Medicine, ${ }^{\ddagger}$ Microbiology and Immunology, and ${ }^{\S}$ Dermatology, New York Medical College, Valhalla, New York 10595
}

\section{Abstract}

In two clinical trials the mouse antiidiotypic monoclonal antibody (MAb) MF11-30, which bears the internal image of human high-molecular-weight-melanoma-associated antigen (HMW-MAA) was administered by subcutaneous route without adjuvants to patients with stage IV malignant melanoma on day 0,7 , and 28. Additional injections were administered if anti-antiidiotypic antibodies were not found or their titer decreased. In the first phase I trial with 16 patients the initial dose was $0.5 \mathrm{mg}$ per injection and escalated to $4 \mathrm{mg}$ per injection. Neither toxicity nor allergic reactions were observed despite the development of anti-mouse Ig antibodies. Minor responses were observed in three patients.

In a second clinical trial MAb MF11-30 was administered to 21 patients at a dose of $2 \mathrm{mg}$ per injection, since this dose had been shown in the initial study to be effective in inducing anti-antiidiotypic antibodies. Two patients were inevaluable; in the remaining 19 patients, the average duration of treatment was 34 wk. In this trial as well, neither toxicity nor allergic reactions were observed. 17 of the 19 immunized patients increased the levels of anti-mouse Ig antibodies and 16 developed antibodies that inhibit the binding of antiidiotypic MAb MF11-30 to the immunizing anti-HMW-MAA MAb 225.28. One patient increased the level of anti-HMW-MAA antibodies. One patient achieved a complete remission with disappearance of multiple abdominal lymph nodes for a duration of 95 wk. Minor responses were observed in three patients.

These results suggest that mouse antiidiotypic MAb that bear the internal image of HMW-MAA may be useful reagents to implement active specific immunotherapy in patients with melanoma. (J. Clin. Invest. 1990. 86:2136-2144.) Key words: efficacy • toxicity

\footnotetext{
This work was presented in part at the Meeting of the Society of Clinical Oncology held in New Orleans, LA, in May, 1988, and at the Meeting on Idiotype Networks in Biology and Medicine, held in Gennep, The Netherlands, in April, 1989.

Address reprint requests to Dr. A. Mittelman, New York Medical College, Valhalla, NY 10595.

Received for publication 21 February 1990 and in revised form 2 July 1990.
}

J. Clin. Invest.

(C) The American Society for Clinical Investigation, Inc.

0021-9738/90/12/2136/09 \$2.00

Volume 86, December 1990, 2136-2144

\section{Introduction}

The development of monoclonal antibodies to human tumorassociated antigens (TAA) ${ }^{1}$ that meet the criteria to be used as targets for immunotherapy (for review, see 1-3) has rekindled interest in the application of immunotherapeutic approaches to malignant diseases. Among them, the use of antiidiotypic antibodies, i.e., antibodies to determinants expressed on the variable region of anti-TAA antibodies, is attracting much attention, since in animal model systems the immune response induced by this type of active specific immunotherapy is associated with an improvement of the course of the disease (4-6). The rationale underlying this approach is represented by the ability of antiidiotypic antibodies that bear the mirror image of TAA to elicit and/or enhance anti-TAA immune responses; such responses may eventually result in the destruction of tumor cells.

In order to test the usefulness of mouse antiidiotypic MAb elicited with syngeneic anti-TAA MAb to implement active specific immunotherapy, we have selected malignant melanoma as our model system for a number of reasons (7). First, a therapeutic approach based on manipulation of the patient's immune response has a potential for success in this disease because of the likely role of immunological factors in its pathogenesis and in its clinical course (8). Second, testing of a novel therapeutic approach finds justification in the lack of progress and limited success of available therapeutic modalities in malignant melanoma (9). Third, utilizing mouse MAb, we have identified a membrane-bound melanoma-associated antigen, referred to as HMW-MAA (high-molecular-weight-melanoma-associated antigen). This antigen represents a useful target for active and passive immunotherapy because of its high frequency in melanoma lesions, its limited heterogeneity in melanoma lesions, its high density on melanoma cells, and its restricted distribution in normal tissues (for review, see 10). Fourth, we have availability to use the mouse antiidiotypic MAb MF11-30 to an idiotope within the antigen-combining site of the syngeneic anti-HMW-MAA MAb 225.28. This antiidiotypic MAb bears the mirror image of HMW-MAA, because it induces anti-HMW-MAA antibodies in allogeneic and xenogeneic combinations (Chattopadhyay, P., S. V. Kaveri, J. Rosenberg, N. Byars, J. Starkey, S. Ferrone, and S. Raychadhuri. Submitted for publication.) The aim of this paper is to describe the results of two clinical trials with anti-

1. Abbreviations used in this paper: HMW-MAA, high-molecularweight-melanoma-associated antigen; PBS-T20, PBS supplemented with $0.05 \%$ Tween 20 ; TAA, tumor-associated antigen. 
idiotypic MAb MF11-30, designed to test toxicity and responses in patients with advanced malignant melanoma.

\section{Methods}

Patients. Patients entered into this study were required to have biopsy-proven malignant melanoma. All patients had failed prior surgical therapy, chemotherapy, radiotherapy, and/or therapy with biologic response modifiers. They had to be off all other therapies for at least 4 wk before entering this trial. They were required to have a Karnofsky performance status of $60 \%$ or better, a normal liver function with bilirubin $\leq 2 \mathrm{mg} / \mathrm{dl}$, serum creatinine of $<2 \mathrm{mg} / \mathrm{dl}$, a white blood cell count of $\geq 3,000$ cells $/ \mathrm{mm}^{3}$, and a platelet count of $\geq 100,000 \mathrm{cells} / \mathrm{mm}^{3}$. All patients were required to have disease measurable by physical examination, $x$ ray, and/or CAT scan, and a life expectancy of at least $3 \mathrm{mo}$. Patients had to sign an informed consent.

Sentinel lesions were measured monthly. Complete blood count and liver function tests were performed biweekly. Serum was obtained weekly for analysis and stored at $-20^{\circ} \mathrm{C}$. Response was defined according to guidelines previously described by the National Cancer Institute. Briefly, complete remission was defined as complete disappearance of all measurable tumors for at least $4 \mathrm{wk}$; partial remission was defined as $50 \%$ reduction of the bidimensional diameters of all measurable lesions for at least $4 \mathrm{wk}$; minor remission was defined as $>25 \%$ and $<50 \%$ reduction of the bidimensional diameters of all measurable lesions for at least $4 \mathrm{wk}$; stable disease was defined as no change in the size of all measurable lesions, and progression of disease was defined as a $25 \%$ increase in the size of all measurable lesions.

Cell lines. Cultured human melanoma and lymphoid cells were grown in medium RPMI 1640 supplemented with $10 \%$ FCS and 2 mM L-glutamine.

$M A b$ and conventional antisera. The mouse MAb 149.53, an IgGl, 225.28, an IgG2a, 763.74, an IgGl, and TP41.2, an IgGl, to distinct and spatially distant determinants of HMW-MAA, the corresponding antiidiotypic MAb MF9-10, MF11-30, MK2-23, and TK6-74, all IgGl, the anti-HLA-DQw3 MAb KS13, an IgG2b, the corresponding anti- idiotypic MAb K03-34, an IgGl, the antiintercellular adhesion molecule -1 (ICAM-1) MAb CL207.14, an IgGl, the antiidiotypic MAb F3-C25, an IgGl, elicited with the anti-HLA class II MAb CR11-462, an IgGl, the antiidiotypic MAb F5-963, an IgG2a, elicited with the anti-HLA-DR 1,4,w6, w8, w9, MAb AC1.59, an IgM, and the antiidiotypic MAb T12-105 and T12-211, both IgGl, elicited with the anti-HLA-B7 cross-reacting group MAb KS4, an IgG2b, were developed as described (11-18; Chattopadhyay et al., submitted for publication).

MAb were purified from ascitic fluid by sequential precipitation with caprylic acid and ammonium sulfate (19). $F\left(a b^{\prime}\right)_{2}$ fragments were prepared as described (13). The purity of MAb and $F\left(a b^{\prime}\right)_{2}$ fragment preparations was monitored by SDS-PAGE (20).

Affinity purified goat anti-human Ig antibodies were purchased from Jackson Immuno Research Laboratories, Inc. (Avondale, PA). Antibodies were labeled with ${ }^{125}$ I using the chloramine T (21) or the iodogen (22) method.

Serological assays. The indirect binding assay with whole Ig and $\mathrm{F}\left(\mathrm{ab}^{\prime}\right)_{2}$ fragments of MAb-coated microtiter plates ( $1 \mu \mathrm{g}$ per well), the inhibition assay to measure human anti-antiidiotypic antibodies, and the double determinant immunoassay to measure serum HMW-MAA levels were performed in 96-well U-bottom polyvinylchloride microtiter plates (Dynatech Laboratories, Inc.; Dynatech Corp.; Alexandria, VA) as described $(12,13,23)$. The indirect binding assay with cells, the cross-blocking assay to map determinants recognized by different antibodies, and the inhibition by antiidiotypic MAb of the binding of anti-antiidiotypic antibodies to target cells were performed in 96-well U-bottom microtiter plates (Falcon Labware, Becton, Dickinson \& Co., Oxnard, CA) as described elsewhere $(13,23)$. Absorption was performed by incubating $100 \mu \mathrm{l}$ of patient's serum with $4 \times 10^{6}$ cells for $2 \mathrm{~h}$ at $4^{\circ} \mathrm{C}$ on a rotator. Serum was then harvested by centrifugation.

Immunochemical methods. Antibodies were conjugated to Affigel 10 (Bio-Rad Laboratories, Richmond, CA) $(2 \mathrm{mg} / \mathrm{ml}$ gel) following the manufacturer's instructions. Labeling of cells with ${ }^{125} \mathrm{I}$, solubilization with NP40, indirect immunoprecipitation, SDS-PAGE, and autoradiography were performed as described $(11,24)$.

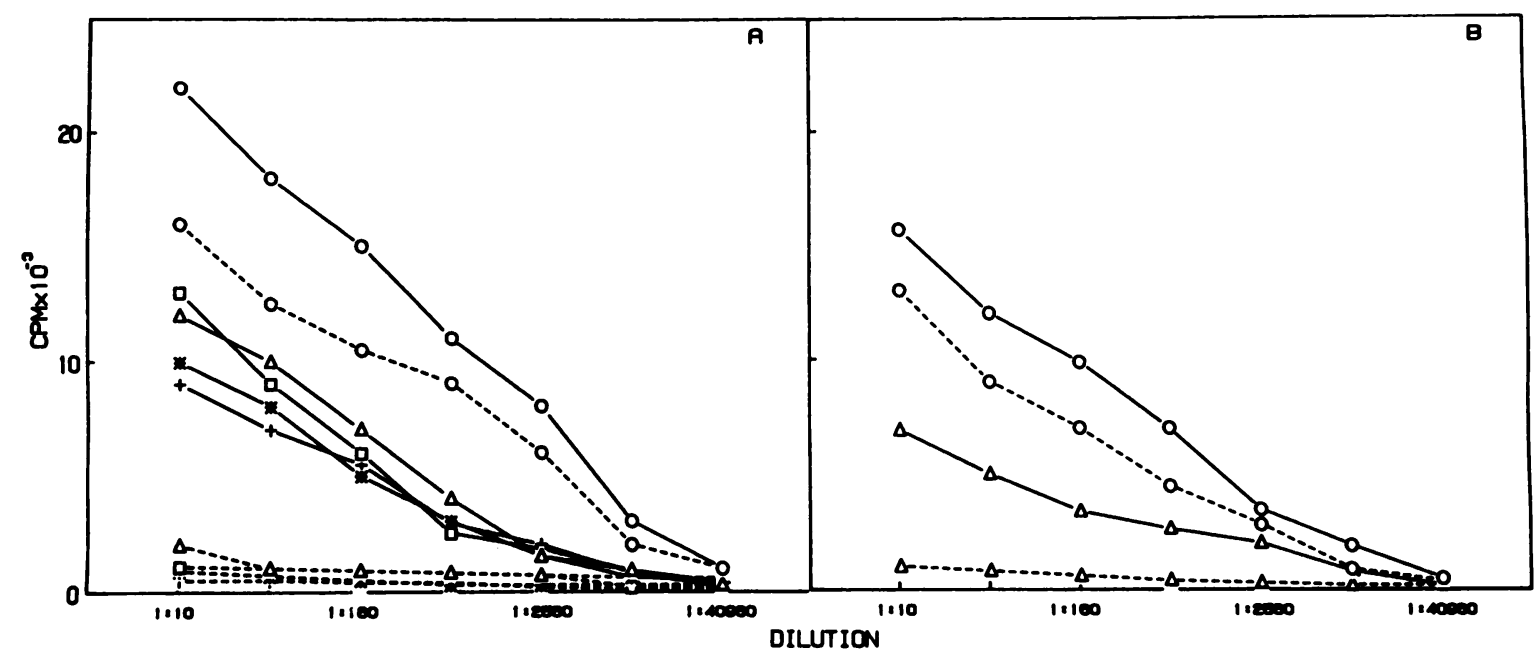

Figure 1. Differential reactivity with the whole IgG and $\mathrm{F}\left(\mathrm{ab}^{\prime}\right)_{2}$ fragments of the immunizing antiidiotypic MAb MF11-30 and unrelated antiidiotypic MAb of serum from patient JB immunized with the mouse antiidiotypic MAb MF11-30. Serum was obtained on day 42 from patient JB who had been immunized on day 0,7 , and 28 with subcutaneous injections of MAb MF11-30 (2 mg per injection). 96-well microtiter plates were coated with whole IgG of the immunizing antiidiotypic MAb MF11-30 (o) and of antiidiotypic MAb F3-C25 (*), F5-963 (+), T12-105 ( $\triangle$ ), and T12-211 (口) $(A)$, or with $\mathrm{F}\left(\mathrm{ab}^{\prime}\right)_{2}$ fragments of the immunizing MAb MF11-30 (O) and of the isotype-matched MAb MK2-23 ( $\triangle$ ) (B). Following washings with PBS-T20 and blocking with PBS supplemented with $1 \%$ dry milk (PBS-dry milk) plates were added with $100 \mu \mathrm{l}$ per well of unabsorbed serum (-) or of serum which had been absorbed with mouse $\mathrm{Ig}(---)$. At the end of a 4-h incubation at $4^{\circ} \mathrm{C}$ plates were washed three times with PBS-T20 and added with ${ }^{125} \mathrm{I}$-anti-human Ig xenoantibodies $\left(1 \times 10^{5} \mathrm{cpm}\right.$ per well). At the end of a 2 -h incubation at room temperature plates were washed five times with PBS-T20. Bound radioactivity was measured in a gamma counter. Results are expressed as bound counts per minute per well. 


\section{Results}

During the initial phase of the clinical trial with MAb MF11-30, an increasing dose of antiidiotypic MAb was administered to patients to determine the dose-related toxicity and to evaluate the development of anti-antiidiotypic antibodies. Seven female and nine male patients with a median age of $58 \mathrm{yr}$ (ranges of 38 and $72 \mathrm{yr}$ ) and with a median performance status of $70 \%$ (ranges of 60 and $80 \%$ ) were entered into this phase I trial. 6 patients had only surgery and 11 patients had been treated with surgery, chemotherapy, and/or radiotherapy. Sites of metastatic disease included skin, lymph nodes, bones, brain, lung, liver, and testicles.

The antiidiotypic MAb MF11-30 was injected subcutaneously on day 0,7 , and 28 . Additional injections were given if anti-antiidiotypic antibodies did not develop or if their titer fell. The number of immunizations per patient ranged between a minimum of 2 and a maximum of 10 with an average of 6 . The average time of treatment per patient was $43 \mathrm{wk}$ with ranges of 3 and $83 \mathrm{wk}$.

Four patients received a starting dose of $0.5 \mathrm{mg}$, two of 1 $\mathrm{mg}$, five of $2 \mathrm{mg}$, and five of $3 \mathrm{mg}$. Of the four patients treated with $0.5 \mathrm{mg}$, one was escalated to $2 \mathrm{mg}$ after six injections over an 18-wk period and another one after three injections over an 8-wk period. Of the five patients treated with a dose of $2 \mathrm{mg}$, one was escalated to $4 \mathrm{mg}$ after three injections over a 5 -wk period. The smallest and the largest cumulative dose of antiidiotypic MAb administered per patient were 1.5 and $17.5 \mathrm{mg}$, respectively, with an average dose of $9.5 \mathrm{mg}$ per patient. None of the immunizations with antiidiotypic MAb MF11-30 was associated with any toxicity and allergic or anaphylactic reactions, although in all the patients anti-mouse Ig antibodies could be detected even before treatment was initiated. $\mathrm{Pa}$ tients' sera reacted with the whole IgG of mouse MAb with a titer ranging between 1:40 and 1:320. This finding, as well as the low reactivity of patients' preimmune sera with $F\left(a b^{\prime}\right)_{2}$ fragments of mouse MAb, is in agreement with the information available in the literature (25-29). The antibodies reacting with whole IgG of mouse MAb were not absorbed by goat and rabbit Ig. After immunization in all the patients, the level of anti-mouse Ig antibodies increased. The time required for the increase in the level of anti-mouse Ig antibodies ranged between a minimum of 1 and a maximum of $4 \mathrm{wk}$. The highest titer of anti-mouse Ig antibodies ranged between a minimum of $1: 320$ and a maximum of $1: 5,120$. The titer of anti-mouse Ig antibodies persisted for as long as $41 \mathrm{wk}$ even in the absence of additional boosters. The reactivity of the immune sera was higher with the whole IgG and with the $F\left(a b^{\prime}\right)_{2}$ fragments of the immunizing MAb MF11-30 than with isotype matched mouse MAb, in terms of both bound counts per minute and titer. Furthermore, absorption of immune sera with $\mathrm{MAb}$ MF11-30 removed their reactivity with all the MAb tested. On the other hand, immune sera reacted with MAb MF11-30 following absorption with isotype matched MAb. Representative results are shown in Fig. 1.

Serum drawn weekly from each patient was tested for its ability to inhibit the binding of the antiidiotypic $\mathrm{MAb}$ MF11-30 to the anti-HMW-MAA MAb 225.28. The inhibitory activity reflects the development of anti-antiidiotypic antibodies, since it was not affected by the removal of antiisotype antibodies by absorption with isotype-matched mouse MAb. Representative results are shown in Fig. 2. The 2.0-mg dose level was the lowest dose to induce anti-antiidiotypic antibodies with sustained titers. The $0.5-\mathrm{mg}$ dose induced low titer anti-antiidiotypic antibodies only in one of the four treated patients following 9 wk of treatment, although it increased anti-mouse Ig antibody level with a kinetics similar to that found in patients treated with the $2.0-\mathrm{mg}$ dose (Fig. 3). At the 3.0-mg dose level, patients entered developed anti-antiidiotypic antibodies with a kinetics and a titer similar to those

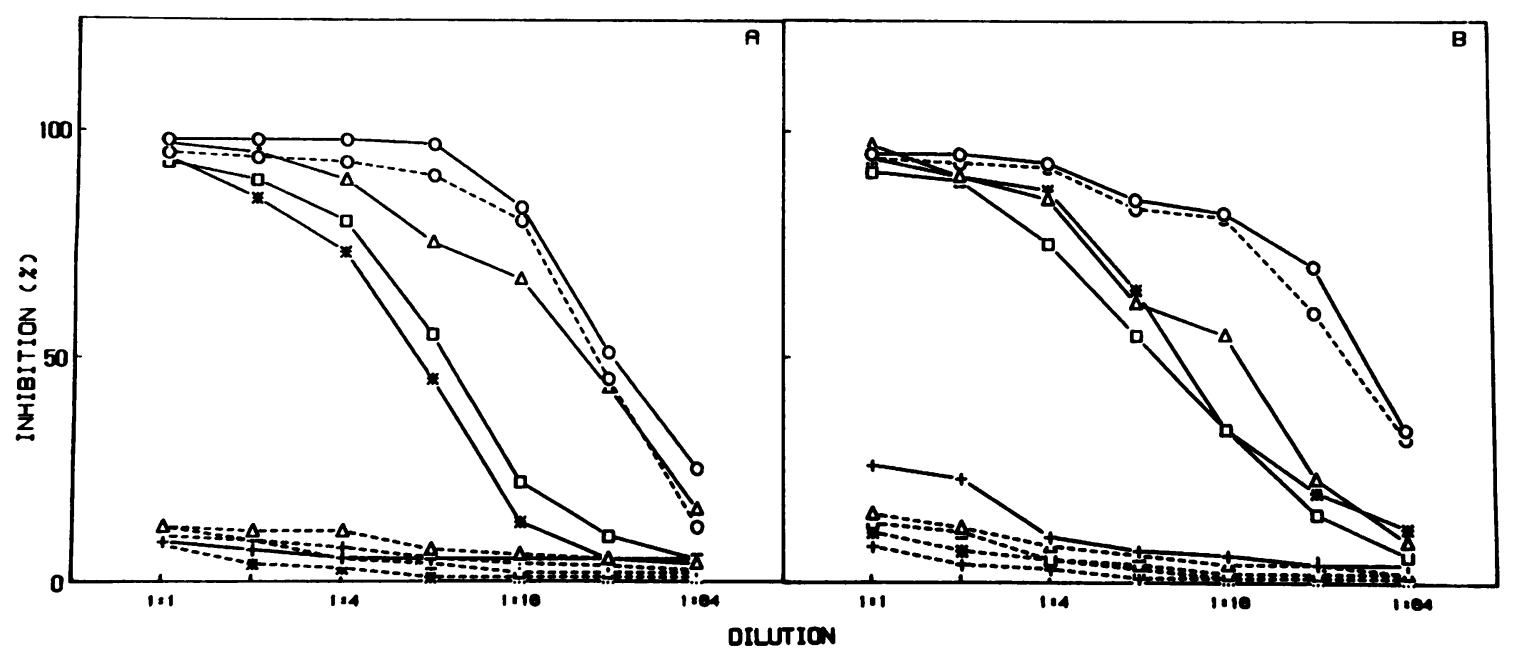

Figure 2. Specificity of anti-antiidiotypic antibodies in patients LB and WK immunized with the mouse antiidiotypic MAb MF11-30. Serum was obtained on day 42 from patient LB $(A)$ and WK $(B)$ who had been immunized on day 0 , 7, and 28 with subcutaneous injections of MAb MF1 1-30 (2 mg per injection). Unabsorbed serum (-) and serum that had been absorbed with mouse Ig (---) were incubated with ${ }^{125} \mathrm{I}$-antiidiotypic MAb MF9-10 (), MF11-30 (0), MK2-23 ( $\triangle)$, TK6-74 (*), and K03-34 (+) $\left(2 \times 10^{5} \mathrm{cpm}\right)$ for $4 \mathrm{~h}$ at $4^{\circ} \mathrm{C}$. Then the mixture was added to anti-HMW-MAA MAb $149.53(\square), 225.28(0), 763.74(\Delta)$, TP41.2 (*), and KS13 (+) coated 96-well microtiter plates (1 $\mu \mathrm{g} /$ well). At the end of a 2-h incubation at room temperature, plates were washed five times with PBS-T20. Bound radioactivity was measured in a gamma counter. Results are expressed as percent inhibition of the binding of ${ }^{125}$ I-antiidiotypic MAb to the corresponding anti-HMW-MAA MAb as compared with binding performed in the presence of preimmune serum. 


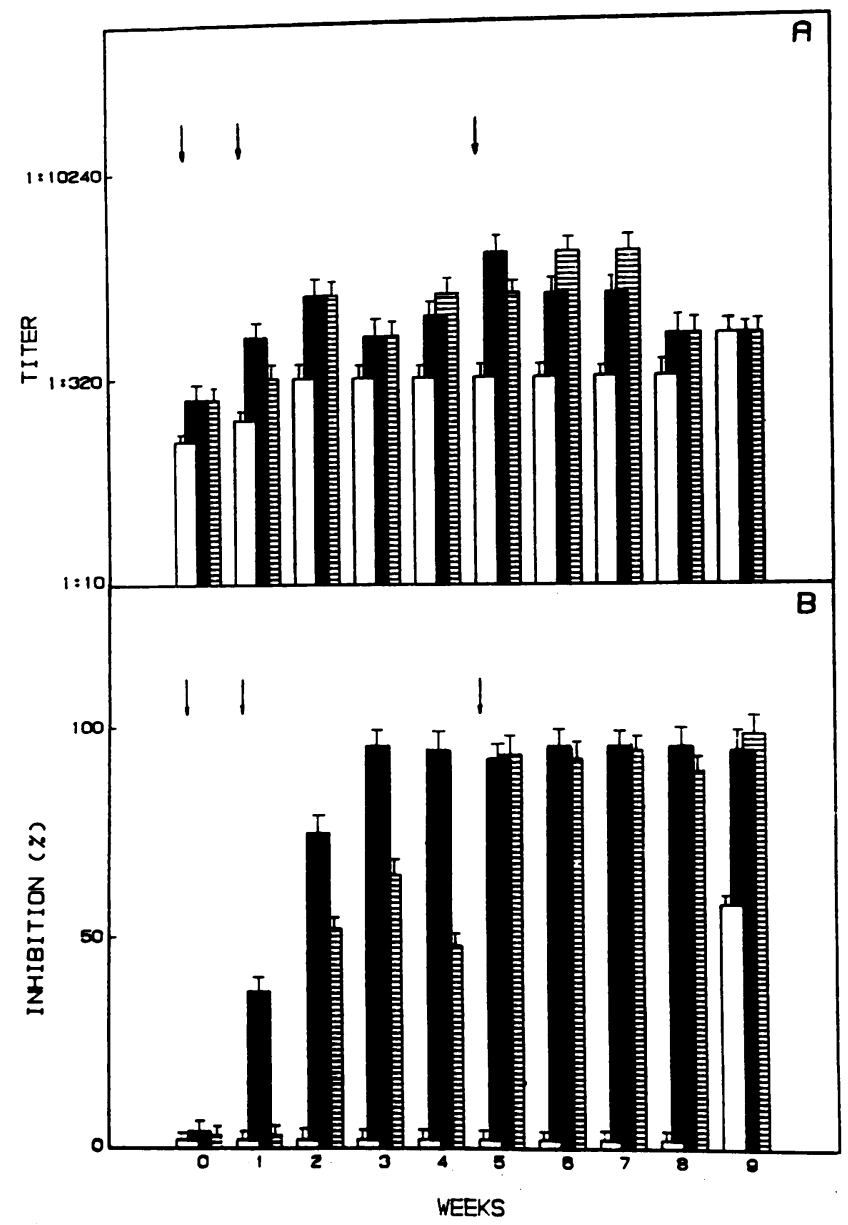

Figure 3. Dose-dependent induction of anti-mouse Ig antibodies and of anti-antiidiotypic antibodies in patients immunized with the mouse antiidiotypic MAb MF11-30. Patients were immunized on the days indicated by the arrows with subcutaneous injections of MAb MF11-30 (0.5 [ㅁ], 2 [], or 3 []ㅣ mg per injection). Sera were drawn weekly and tested for the level of anti-mouse Ig antibodies in a binding assay $(A)$ and of anti-antiidiotypic antibodies, i.e., antibodies that inhibit the binding of ${ }^{125} \mathrm{I}-\mathrm{MAb}$ MF11-30 to anti-HMWMAA MAb 225.28, in an inhibition assay $(B)$.

found in the patients treated with $2.0 \mathrm{mg}$ (Fig. 3). Antibodies reacting with cultured human melanoma cells Colo 38 were not detected in any of the immunized patients. Minor responses were observed in three patients with a decrease in pulmonary, testicular, and/or cutaneous lesions. The response lasted 83, 36, and 34 wk.

The 2-mg dose was then selected to implement an efficacy trial in eleven male and ten female patients with a median age of $54 \mathrm{yr}$ (ranges of 27 and $74 \mathrm{yr}$ ) and with a mean performance status of $70 \%$ (ranges of 60 and $90 \%$ ). Metastatic sites included skin in seven patients, lymph nodes in five, bones in two, brain in four, lung in two, liver in six, and local recurrence of disease in two. In terms of prior therapy, 6 patients had been treated only with surgery; the remaining 15 had received combinations of immunotherapy, which included IL-2, alpha interferon, and the mouse anti-GD3 ganglioside MAb R24; chemotherapy, which included cisplatin, DTIC, and nitrosourea; and/or radiation therapy to painful bone disease or brain metastases. The immunization schedule was like the one in the initial trial. The number of immunizations per patient ranged between a minimum of 3 and a maximum of 12 with an average of 7.5 per patient. The time of treatment ranged between a minimum of 4 and a maximum of $95 \mathrm{wk}$ with an average of $47 \mathrm{wk}$.

In this trial also, no toxicity was observed. Extensive serological evaluation was carried out in only 19 patients; their clinical characteristics are summarized in Table I. Two patients were excluded from the study, since they were treated for less than $4 \mathrm{wk}$ because of progression of disease. Before the immunization, eight patients had an anti-mouse Ig antibody titer $\leq 1: 160$, eight between $1: 160$ and 1:640, and three higher than 1:640. Following immunization no change was detected in the titer of anti-mouse Ig antibodies in two patients, while an increase was observed in the remaining 17 . The time required for the increase ranged between 1 and 6 wk with an average time of $3.5 \mathrm{wk}$. Anti-mouse Ig antibody titers persisted for $54 \mathrm{wk}$ in the absence of additional boosters.

Anti-antiidiotypic antibodies were not detected in any of the patients before the immunization started; 16 of the 19 patients developed anti-antiidiotypic antibodies. The time for their development ranged between a minimum of 2 and a maximum of $10 \mathrm{wk}$ with an average time of $6 \mathrm{wk}$. The titer of anti-antiidiotypic antibodies, i.e., the dilution of serum which inhibited the binding of ${ }^{125}$ I-MAb MF1 1-30 to MAb 225.28 by $90 \%$, was at least $1: 8$ in seven patients, $1: 4$ in eight, and $1: 2$ in one (Table I). Patients' immune sera did not inhibit the binding of ${ }^{125}$ I-antiidiotypic MAb K03-34 to the corresponding anti-HLA-DQw3 MAb KS13, but inhibited the binding of ${ }^{125}$ I-antiidiotypic MAb MF9-10, MK2-23, and TK6-74 to the corresponding anti-HMW-MAA MAb 149.53, 763.74, and TP41.2. This inhibitory effect was lost following absorption with mouse IgG, which however did not affect the inhibition of the binding of ${ }^{125}$ I-antiidiotypic MAb MF11-30 to MAb 225.28. In the seven patients with a titer of anti-antiidiotypic antibodies of at least 1:8, the serum level of HMW-MAA did not change throughout the period of observation, while in the remaining 12 , the level of serum HMW-MAA increased during the treatment. Representative results are shown in Fig. 4.

Before immunization with MAb MF11-30, antibodies reacting with cultured human melanoma cells were detected only in patient MM. After immunization with MAb MF1 1-30, antibodies reacting with cultured melanoma cells were not induced in any patient; however, the level of antibodies increased in patient MM (Fig. 5). The increase occurred later than the development of anti-antiidiotypic antibodies which inhibit the binding of ${ }^{125} \mathrm{I}-\mathrm{MAb}$ MF1 1-30 to MAb 225.28. The latter reached their maximal titer earlier than the antibodies reacting with melanoma cells. It should be noted that serum from this patient reacted also with cultured human B and $T$ lymphoid cells, although to a lower extent than with melanoma cells (Fig. 5). After absorption with human lymphoid cells, the absorbed serum lost its reactivity with lymphoid cells, but continued to react with cultured melanoma cells, although to a lower extent than the unabsorbed serum (Fig. 6).

The serum from patient MM did not immunoprecipitate any component from ${ }^{125}$ I-labeled cultured melanoma cells, probably because of the low affinity and/or level of antibodies induced by antiidiotypic MAb MF11-30. Therefore, to prove their reactivity with HMW-MAA, sera were tested with HMW-MAA purified from an extract of cultured melanoma 
Table I. Clinical Characteristics of Patients with Melanoma Treated with the Mouse Antiidiotypic MAb MF11-30

\begin{tabular}{|c|c|c|c|c|c|c|c|}
\hline Name & $\begin{array}{l}\text { Age } \\
\text { (yrs) }\end{array}$ & Sex & $\begin{array}{l}\text { Duration of } \\
\text { disease (mo) }\end{array}$ & Site of primary lesion & Site of metastases & $\begin{array}{l}\text { Anti-antiidio- } \\
\text { typic antibodies* }\end{array}$ & $\begin{array}{c}\text { Survival } \\
\text { (wk) }\end{array}$ \\
\hline $\mathrm{CS}$ & 55 & $\mathbf{F}$ & 45 & Back & Lymph node & $1: 16$ & 95 \\
\hline MK & 74 & $\mathbf{F}$ & 37 & Nasopharynx & Local recurrence & $1: 16$ & 77 \\
\hline GS & 52 & $\mathbf{F}$ & 73 & Shoulder & Lung, spleen, bladder & $1: 16$ & 20 \\
\hline MT & 27 & $\mathbf{M}$ & 36 & Chest wall & Liver, spleen & $1: 8$ & 45 \\
\hline $\mathrm{CD}$ & 34 & $\mathbf{M}$ & 12 & Unknown & Bone & $1: 8$ & 16 \\
\hline DG & 63 & $\mathbf{F}$ & 72 & Sinus & Orbit & $1: 4$ & 41 \\
\hline MB & 37 & $\mathbf{M}$ & 16 & Back & Liver & $1: 4$ & 8 \\
\hline JS & 64 & $\mathbf{M}$ & 153 & Back & Lung, liver, spleen & $1: 2$ & 47 \\
\hline PG & 37 & $\mathbf{F}$ & 96 & Neck & Skin, brain, colon & $1: 4$ & 57 \\
\hline OD & 64 & $\mathbf{M}$ & 40 & Chest wall & Liver, spleen & $1: 4$ & 32 \\
\hline $\mathrm{AC}$ & 53 & $\mathbf{F}$ & 125 & Forehead & Skin & $1: 4$ & 53 \\
\hline CW & 33 & $\mathbf{F}$ & 23 & Thigh & Skin, lymph node, brain, breast & 一 $^{\ddagger}$ & 19 \\
\hline WC & 64 & $\mathbf{M}$ & 72 & Shoulder & Lymph node, adrenal gland & - & 9 \\
\hline AS & 53 & $\mathbf{M}$ & 17 & Breast & Lymph node, liver, lymph node & - & 14 \\
\hline
\end{tabular}

* Twofold dilutions of sera were tested for their ability to inhibit the binding of ${ }^{125}$ I-antiidiotypic MAb MF11-30 to anti-HMW-MAA MAb 225.28 in an inhibition assay. Results are expressed as the highest dilution of serum which inhibits the idiotype-antiidiotype reaction by more than $90 \%$. ${ }^{\ddagger}$ Sera did not inhibit the idiotype-antiidiotype reaction.

cells Colo 38 by binding to a 96 -well microtiter plate coated with MAb 149.53. The latter recognizes a distinct and spatially distant determinant from that defined by MAb 225.28 (12). Like MAb 225.28, patient MM's serum reacted with the purified HMW-MAA. The binding is specific, since patient MM's serum did not react with MAb 149.53-coated plates that had been preincubated with an extract of cultured B lymphoid cells LG-2. The antibodies induced by MAb MF11-30 recognize the same (or spatially close) determinant as that reacting with
MAb 225.28, since patient MM's serum did not react with HMW-MAA bound to MAb 225.28-coated microtiter plates (Fig. 7). Conversely, coating of melanoma cells with patient MM's serum inhibited the binding of ${ }^{125}$ I-anti-HMW-MAA MAb 225.28 by more than $50 \%$. The inhibition is specific since patient MM's serum did not affect the binding of ${ }^{125} \mathrm{I}$ anti-ICAM-1 MAb CL207.14 to melanoma cells (Fig. 8). The antibodies induced in patient MM by antiidiotypic MAb MF1 1-30 express the corresponding idiotope in their antigen-

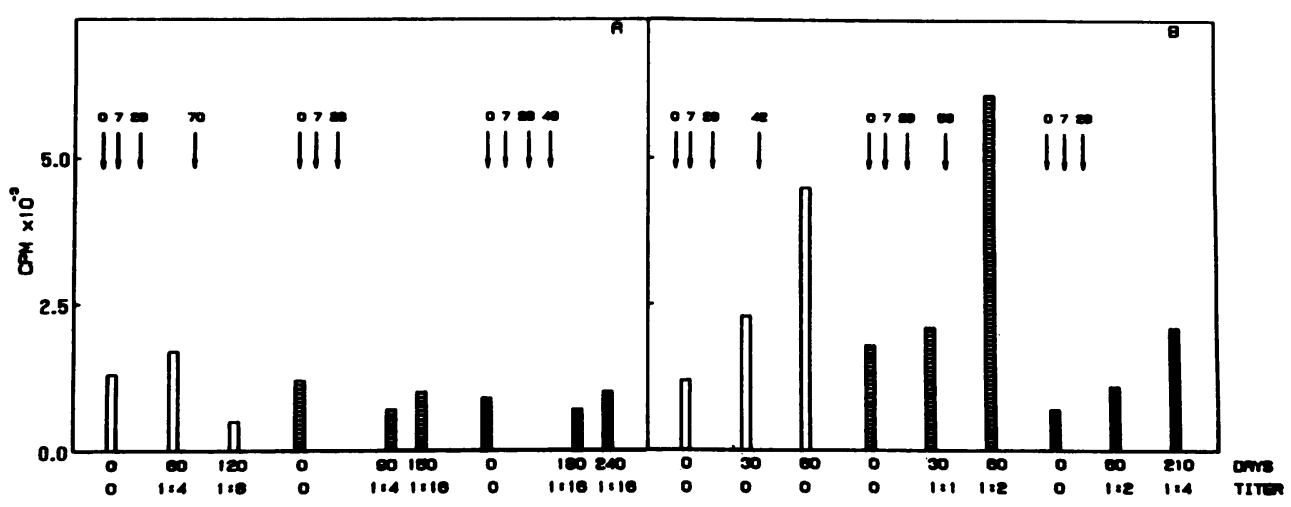

Figure 4. Level of serum HMW-MAA in patients who had developed high or low levels of anti-antiidiotypic antibodies following immunization with the mouse antiidiotypic MAb MF11-30. Sera were obtained on the indicated days from patients PB ( $\square$ ), CS ( $\square$ ), and MK ( $\square$ ), $(A)$, CW $(\square)$, WK (E), and AC ( $\square),(B)$, who had been immunized on the days indicated by the arrows with subcutaneous injections of MAb MF11-30 (2 mg per injection). Serum was added to anti-HMW-MAA MAb $149.53\left(1 \mu \mathrm{g} /\right.$ well)-coated plates. At the end of a 4-h incubation at $4^{\circ} \mathrm{C}$ plates were washed three times with PBS-T20 and incubated for $2 \mathrm{~h}$ at $4^{\circ} \mathrm{C}$ with mouse $\mathrm{Ig}(1 \mu \mathrm{g}$ per well) to inhibit the reactivity of anti-mouse Ig antibodies with ${ }^{125} \mathrm{I}$-anti-HMW-MAA MAb 763.74. Then, plates were washed three times with PBS-T20 and added with ${ }^{125} \mathrm{I}-\mathrm{MAb} 763.74$ (2 $\times 10^{5} \mathrm{cpm}$ per well). At the end of a 2-h incubation at room temperature plates were washed five times with PBS-T20. Bound radioactivity was measured in a gamma counter. Results are expressed as bound counts per minute per well. 


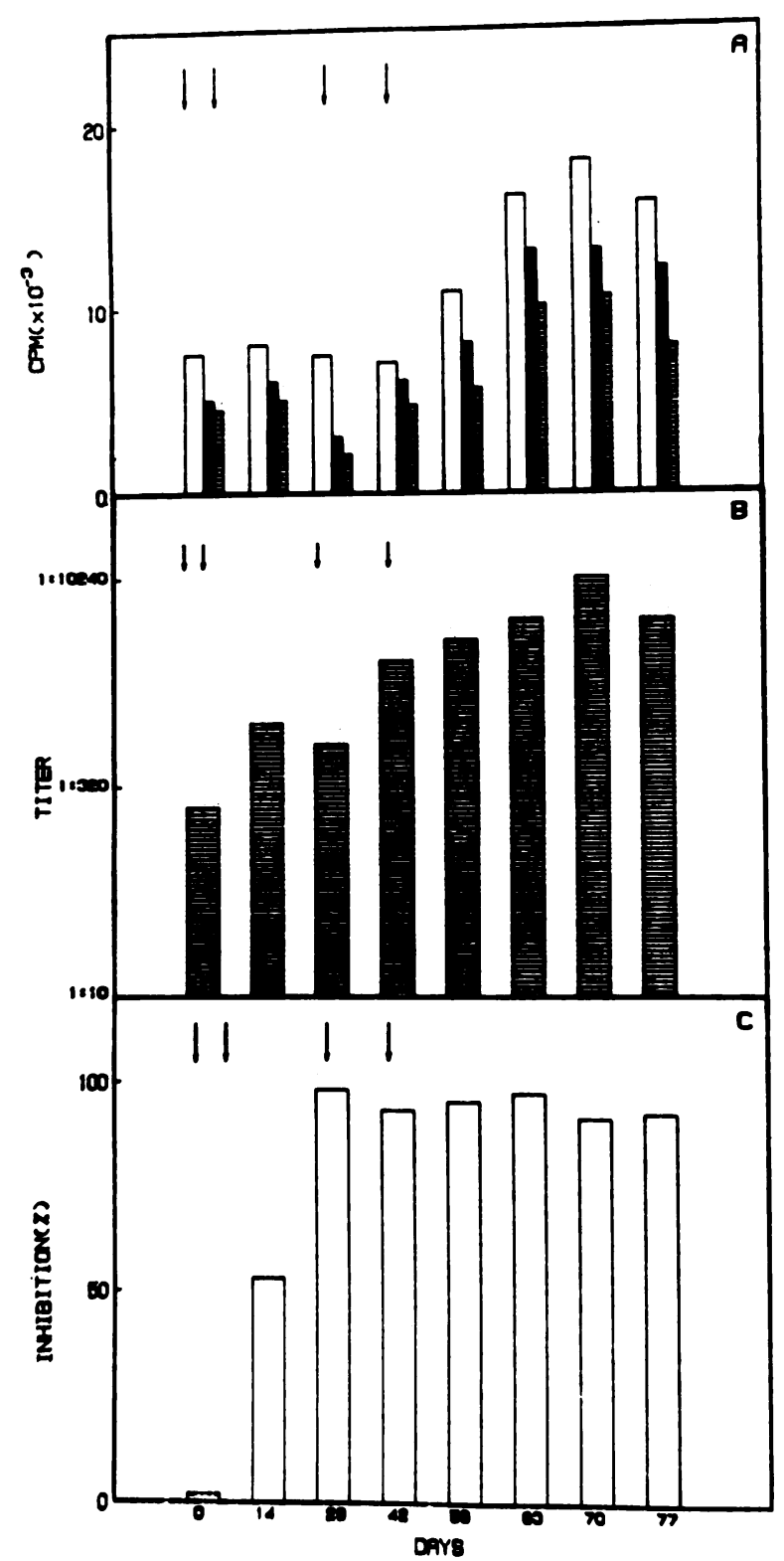

Figure 5. Kinetics of the development of antibodies reacting with cultured human cells, of anti-mouse Ig antibodies, and of anti-antiidiotypic antibodies in patient MM immunized with the mouse antiidiotypic MAb MF11-30. Patient MM was immunized on the days indicated by the arrows with subcutaneous injections of MAb MF11-30 (2 mg per injection). Serum was drawn weekly. Each sample was tested with cultured melanoma cells Colo 38 (), cultured B lymphoid cells LG-2 (E), and cultured T lymphoid cells MOLT-4 (a) in a binding assay with ${ }^{125} \mathrm{I}$-anti-human Ig xenoantibodies $(A)$, with the antiidiotypic MAb MF1 1-30 in a binding assay with ${ }^{125}$ I-antihuman Ig xenoantibodies $(B)$, and in an inhibition assay with ${ }^{125} \mathrm{I}$ MAb MF1 1-30 and anti-HMW-MAA MAb 225.28 (C).

combining site, since the binding of patient MM's serum to melanoma cells was blocked by the immunizing antiidiotypic MAb MF11-30 in a dose-dependent fashion. The inhibition is specific, since incubation with the unrelated antiidiotypic MAb K03-34 did not affect the binding of patient MM's serum to melanoma cells (Fig. 9).

Immunization with the antiidiotypic MAb MF11-30 was associated with a complete remission in one patient who

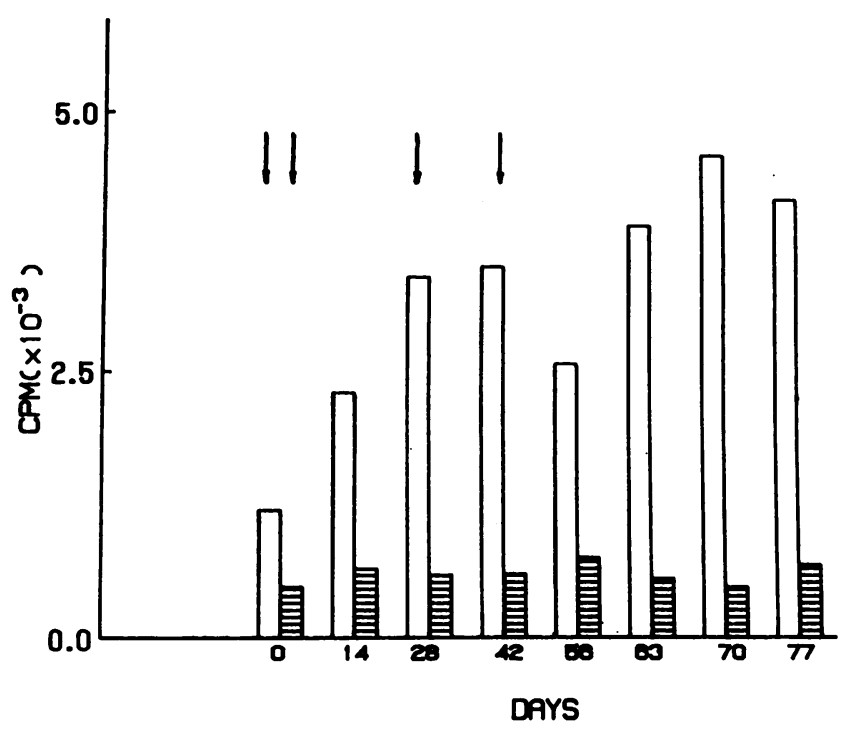

Figure 6. Differential reactivity with cultured human melanoma cells Colo 38 and with cultured human B lymphoid cells LG-2 of serum from patient $\mathrm{MM}$ immunized with the mouse antiidiotypic MAb MF11-30. Patient MM was immunized on the days indicated by the arrows with subcutaneous injections of MAb MF11-30 (2 mg per injection). Serum was drawn weekly. Following absorption with cultured B lymphoid cells LG-2 each sample was tested with cultured melanoma cells Colo 38 (ㅁ) and with cultured B lymphoid cells LG-2 (뭉) in a binding assay with ${ }^{125} \mathrm{I}$-anti-human Ig xenoantibodies.

achieved disease-free status after $52 \mathrm{wk}$ from the start of therapy. This patient presented with a primary lesion resected from the back. Two years later she developed axillary and inguinal lymph node metastasis; both were resected. Before entering this trial, this patient had diffuse metastatic disease to her pelvic and paraaortic lymph nodes. This patient remained disease-free for $\mathbf{4 3} \mathrm{wk}$. Minor responses were observed in three patients with the duration of 14,55 , and $77 \mathrm{wk}$. In addition, it is noteworthy that the average survival of the seven patients who had developed anti-antiidiotypic antibodies with a titer of at least 1:8 and displayed no marked changes in the level of serum HMW-MAA was 55 wk (ranges of 16 and $95 \mathrm{wk}$ ). On the other hand, the average survival of the remaining 12 patients who developed anti-antiidiotypic antibodies with a titer of 1:4 or less and displayed an increase in the level of serum HMW-MAA was 19 wk (ranges of 8 and 57 wk). The difference between the two groups is statistically significant $(P<0.01)$.

\section{Discussion}

This study describes the results of a phase I clinical trial in patients with stage IV malignant melanoma using the mouse antiidiotypic MAb MF11-30 elicited with the syngeneic antiHMW-MAA MAb 225.28. To the best of our knowledge, this is the first clinical trial of active specific immunotherapy with mouse antiidiotypic MAb in patients with solid tumors. The trial implemented by Herlyn et al. (30) in patients with colorectal carcinoma used antiidiotypic antibodies isolated from a goat immunized with a mouse anti-human TAA MAb. Furthermore, the trial with mouse antiidiotypic MAb in patients with lymphoma $(31,32)$ is a type of passive immunotherapy 


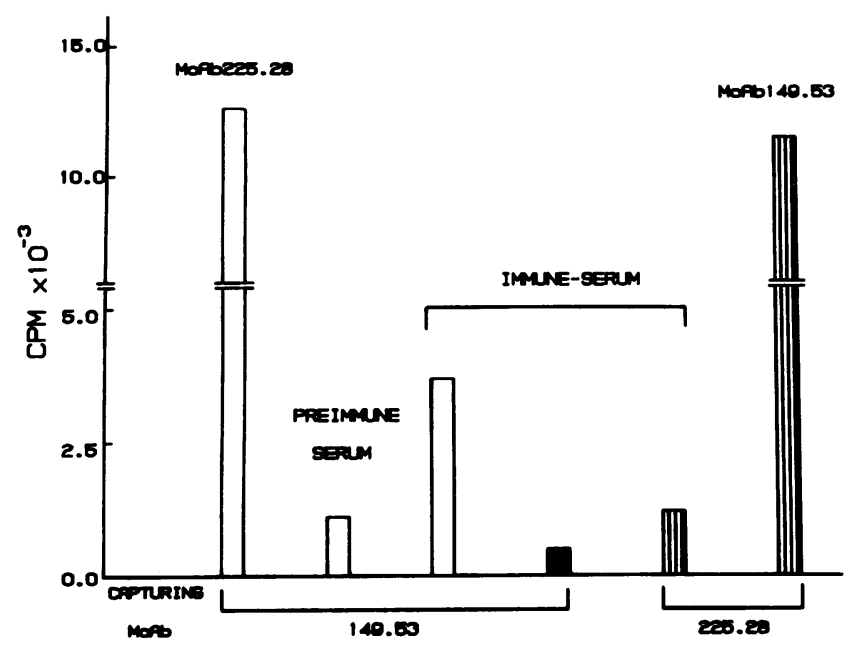

Figure 7. Reactivity with HMW-MAA of serum from patient MM immunized with the mouse antiidiotypic MAb MF11-30. Serum was obtained on day 63 from patient MM who had been immunized on day $0,7,28$, and 42 with subcutaneous injections of MAb MF11-30 ( 2 mg per injection). An NP40 extract of cultured human melanoma cells Colo 38 was incubated for $4 \mathrm{~h}$ at $4^{\circ} \mathrm{C}$ in microtiter plates coated with anti-HMW-MAA MAb 149.53 (ㅁ) or MoAb 225.28 (들) (1 $\mu \mathrm{g}$ per well). Following three washings with PBS-T20, preimmune and immune sera ( $50 \mu \mathrm{l}$ per well) were added. At the end of a 4-h incubation at $4^{\circ} \mathrm{C}$, plates were washed three times with PBS-T20 and added with ${ }^{125} \mathrm{I}$-anti-human IgG $+\mathrm{M}$ xenoantibodies $\left(2 \times 10^{5} \mathrm{cpm}\right.$ per well). Incubation was continued for an additional $2 \mathrm{~h}$ at room temperature. Plates were then washed five times with PBS-T20 and dried. Bound radioactivity was measured in a gamma counter. Results are expressed as bound counts per minute per well. MAb 149.53 coated wells incubated with an NP40 extract of cultured B lymphoid cells LG-2 that do not express HMW-MAA ( 1 ) were used as controls. The binding of HMW-MAA to MAb 149.53 and to MAb 225.28-coated wells was monitored with ${ }^{125}$ I-MAb 225.28 and with ${ }^{125} \mathrm{I}-\mathrm{MAb} 149.53$, respectively.

which relies on the direct interaction of antiidiotypic antibodies with tumor cells.

Four results of our investigations are noteworthy. First, the most reassuring aspect of our trial has been the lack of side effects in patients with stage IV melanoma immunized with repeated injections of mouse antiidiotypic MAb MF11-30 in spite of the development of anti-mouse Ig antibodies. The therapy is well tolerated and therefore could be administered on an outpatient basis. This has greatly facilitated the recruitment of patients to our clinical trial. Second, at least seven patients showed regression of cutaneous and/or visceral metastases. The low frequency of clinical remissions in this phase I trial with a mouse antiidiotypic MAb that bears the mirror image of HMW-MAA is not surprising, since therapy was administered only to patients with advanced disease. They are likely to have impairment of their immune system because of the disease and/or of previous chemotherapy and radiotherapy. A cause-effect relationship between the immunization with the antiidiotypic MAb MF1 1-30 and the clinical response has not been formally proven in our investigations. However, the potential role of immune phenomena triggered by the injection of the antiidiotypic MAb MF11-30 in the responses we have observed is suggested by the significantly longer survival in patients who developed a high titer of anti-antiidiotypic

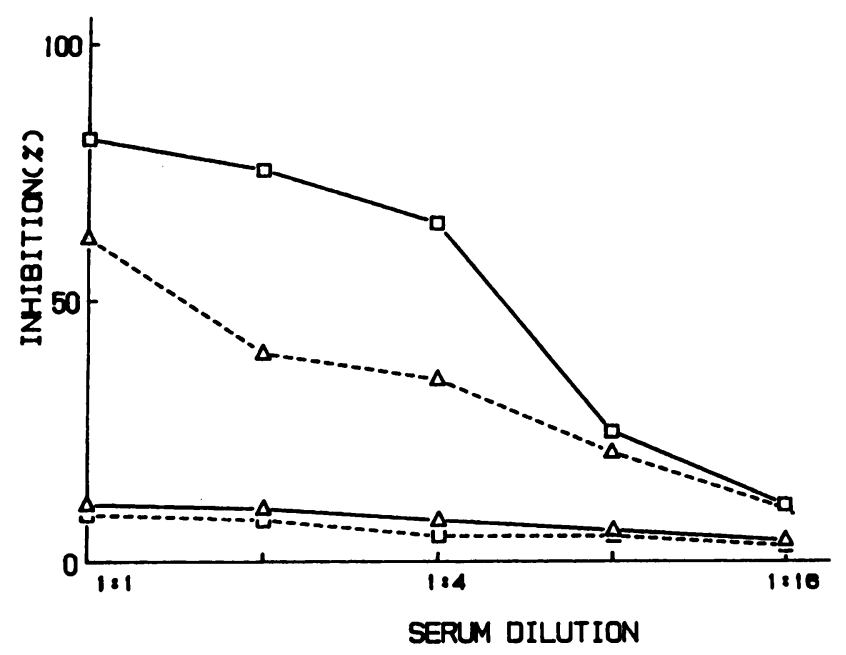

Figure 8. Inhibition of the binding of anti-HMW-MAA MAb 225.28 to cultured human melanoma cells Colo 38 by sera from patient MM immunized with the mouse antiidiotypic MAb MF11-30. Sera were obtained on day 42 (---) and 63 (-) from patient MM who had been immunized on day $0,7,28$, and 42 with subcutaneous injections of MAb MF11-30 (2 mg per injection). Cultured melanoma cells Colo 38 were incubated with patient MM's serum for $2 \mathrm{~h}$ at $4^{\circ} \mathrm{C}$. Then the supernatant was carefully removed and cells were added with ${ }^{125} \mathrm{I}$-anti-HMW-MAA MAb 225.28 (ㅁ). Following an additional 2-h incubation at $4^{\circ} \mathrm{C}$, cells were washed with PBS supplemented with $1 \%$ BSA (PBS-BSA) and bound radioactivity was measured in a gamma counter. Results are expressed as percent inhibition of the binding of ${ }^{125}$ I-labeled MAb to melanoma cells as compared with binding performed in the presence of preimmune serum. ${ }^{125}$ I-anti-ICAM-1 MAb CL207.14 $(\Delta)$ was used as a specificity control.

antibodies. Third, the detection of anti-HMW-MAA antibodies in patient $M M$ following immunization with the mouse antiidiotypic MAb MF11-30 shows for the first time that mouse antiidiotypic MAb that bear the internal image of a human MAA identified with mouse MAb can induce immunity to the corresponding MAA in patients. At least two possibilities may be envisioned for the detection of anti-HMWMAA antibodies in only one of the patients immunized with MAb MF11-30. The results we have obtained in animal model systems (Chattopadhyay et al., submitted for publication) suggest that this finding may reflect the low immunogenicity of the idiotope of MAb MF11-30 that mimics the HMW-MAA, when injected without conjugation to a carrier and mixing with an adjuvant. Neither reagent could be used for ethical reasons in this first clinical trial because of the lack of information about the toxicity in patients with melanoma of mouse antiidiotypic MAb in the HMW-MAA system. An alternative, but not exclusive, possibility is that anti-HMW-MAA antibodies are induced by MAb MF11-30, but are not detectable, since they are absorbed by melanoma lesions and/or are complexed with the HMW-MAA and with antiidiotypic antibodies. The latter may be formed following the triggering by the injection of MAb MF11-30 of the idiotypic cascade in the HMW-MAA system. Last, human and mouse anti-HMWMAA antibodies share the idiotope recognized by the antiidiotypic MAb MF11-30. This phenomenon is not unique to the HMW-MAA system, since sharing of idiotopes among 


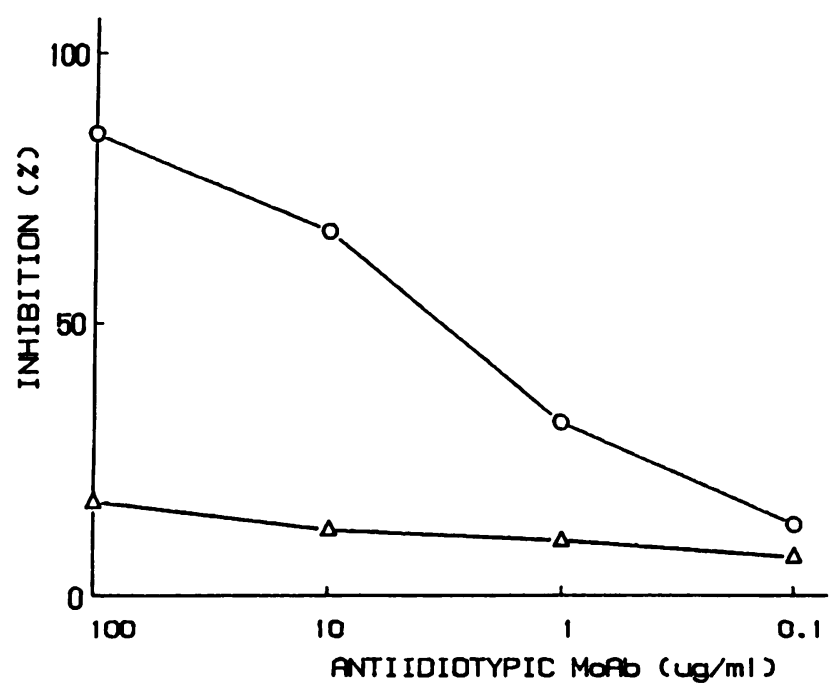

Figure 9. Inhibition by antiidiotypic MAb MF11-30 of the binding to cultured human melanoma cells Colo 38 of serum from patient MM immunized with the mouse antiidiotypic MAb MF11-30.

Serum was obtained on day 63 from patient MM who had been immunized on day $0,7,28$, and 42 with subcutaneous injections of MAb MF1 1-30 (2 mg per injection). Serum from patient MM was incubated with the antiidiotypic MAb MF11-30 (o - o) for $2 \mathrm{~h}$ at room temperature. Then the mixture was added to cultured melanoma cells Colo 38 and the incubation was continued for an additional $2 \mathrm{~h}$ at $4^{\circ} \mathrm{C}$. Then cells were washed with PBS-BSA and incubated with ${ }^{125} \mathrm{I}$-anti-human Ig xenoantibodies. Following additional washings bound radioactivity was measured in a gamma counter. Results are expressed as percent inhibition of the binding of ${ }^{125} \mathrm{I}$-labeled antibodies to melanoma cells as compared to binding performed in the presence of mouse Ig. The unrelated antiidiotypic MAb K03-34 $(\Delta-\Delta)$ was used as a specificity control.

xenogeneic antibodies has been described in several antigenic systems $(29,32-36)$.

The results we have obtained justify the continuation of the clinical trial with mouse antiidiotypic MAb that bear the internal image of HMW-MAA. Future studies will have to analyze the development of cell-mediated immunity to HMWMAA in patients treated with antiidiotypic MAb in view of its potential role in the clinical course of the disease (37). Furthermore, the immunization protocol has to be optimized and criteria have to be identified to select patients who are likely to benefit from this type of active specific immunotherapy.

\section{Acknowledgments}

The authors acknowledge the excellent secretarial assistance of Mrs. Cheryl R. Rau and Mrs. Harriett V. Harrison.

This investigation was supported by Public Health Service grant CA37959 awarded by the National Cancer Institute, Dept. of Health and Human Services, and by grant IM-500A awarded by the American Cancer Society.

\section{References}

1. Reisfeld, R. A., and D. A. Cheresh. 1987. Human tumor antigens. Adv. Immunol. 40:323-377.

2. Herlyn, M., and H. Koprowski. 1988. Melanoma antigens: immunological and biological characterization and clinical significance. Annu. Rev. Immunol. 6:285-308.
3. Natali, P. G., R. Fawwaz, D. J. Ruiter, A. Bigotti, T. Kageshita, M. Temponi, and S. Ferrone. 1989. Immunodiagnostic and immunotherapeutic applications of anti human melanoma associated antigen monoclonal antibodies. In Carcinogenesis-A Comprehensive Survey. Vol. 11: Skin Tumors: Experimental and Clinical Aspects. C. J. Conti, T. J. Slaga, and A. J. P. Klein-Szanto, editors. Raven Press, Ltd., New York. 133-164.

4. Nelson, K. A., E. George, C. Swenson, J. W. Forstrom, and K. E. Hellstrom. 1987. Immunotherapy of murine sarcomas with autoanti-idiotypic monoclonal antibodies which bind to tumor-specific $\mathrm{T}$ cells. J. Immunol. 139:2110-2117.

5. Powell, T. J., R. Spann, M. Nguyenduc, and E. W. Lamon. 1989. Induction of effective immunity to moloney murine sarcoma virus using monoclonal anti-idiotypic antibody as immunogen. J. Immunol. 142:1318-1324.

6. Chen, J. J., Y. Saeki, L. Shi, and H. Kohler. 1988. Tumor idiotype vaccines. VI. Synergistic anti-tumor effects with combined "internal image" anti-idiotypes and chemotherapy. J. Immunol. 143:1053-1057.

7. Kageshita, T., Z. J. Chen, J. W. Kim, M. Kusama, U. M. Kekish, T. Trujillo, M. Temponi, A. Mittelman, and S. Ferrone. 1988. Murine anti-idiotypic monoclonal antibodies to syngeneic antihuman high molecular weight-melanoma associated antigen monoclonal antibodies: development, characterization and clinical applications. Pigm. Cell Res. Suppl. 1:185-191.

8. Mastrangelo, M. J., A. R. Baker, and H. R. Katz. 1985. Cutaneous melanomas. In Cancer-Principles and Practice of Oncology. V. T. DeVita, Jr., J. Hellman, and A. Rosenberg, editors. J. B. Lippincott Co., Philadelphia. 1371-1422.

9. Balch, C. M., S. J. Soong, H. M. Shaw, and G. W. Milton. 1985. An analysis of prognostic factors in 4,000 patients with cutaneous melanoma. In Clinical Management and Treatment Results Worldwide. C. M. Balch and G. W. Milton, editors. J. B. Lippincott Co., Philadelphia. 321-352.

10. Ferrone, S., M. Temponi, D. Gargiulo, G. A. Scassellati, R. Cavaliere, and P. G. Natali. 1988. Selection and utilization of monoclonal antibody-defined melanoma associated antigens for immunoscintigraphy in patients with melanoma. In Radiolabeled Monoclonal Antibodies for Imaging and Therapy. Potential, Problems and Prospects. S. C. Srivastava, editor. Plenum Publishing Corp., New York. 55-73.

11. Wilson, B. S., K. Imai, P. G. Natali, and S. Ferrone. 1981. Distribution and molecular characterization of a cell-surface and a cytoplasmic antigen detectable in human melanoma cells with monoclonal antibodies. Int. J. Cancer. 28:293-300.

12. Giacomini, P., F. Veglia, P. C. Fei, T. Rehle, P. G. Natali, and S. Ferrone. 1984. Level of a membrane-bound high-molecular-weight melanoma-associated antigen and a cytoplasmic melanoma-associated antigen in surgically removed tissues and in sera from patients with melanoma. Cancer Res. 44:1281-1287.

13. Kusama, M., T. Kageshita, Z. J. Chen, and S. Ferrone. 1989. Characterization of syngeneic antiidiotypic monoclonal antibodies to murine anti-human high molecular weight melanoma associated antigen monoclonal antibodies. J. Immunol. 143:3844-3852.

14. Ono, R., I. Sakaguchi, and S. Ferrone. 1989. Modulation by anti-idiotypic monoclonal antibodies of immune lysis mediated by anti-HLA monoclonal antibodies. J. Immunol. 143:1921-1929.

15. Matsui, M., M. Temponi, and S. Ferrone. 1987. Characterization of a monoclonal antibody-defined human melanoma-associated antigen susceptible to induction by immune interferon. J. Immunol. 139:2088-2095.

16. Perosa, F., and S. Ferrone. 1988. Syngeneic antiidiotypic monoclonal antibodies to the murine anti-HLA-DR,DP monoclonal antibody CR 1 1-462. Hum. Immunol. 23:255-269.

17. Perosa, F., and S. Ferrone. 1989. Murine antiidiotypic monoclonal antibodies that bear the internal image of HLA-DR allospecifcities. J. Clin. Invest. 84:907-914.

18. Sakaguchi, K., R. Ono, M. Tsujisaki, P. Richiardi, A. Carbo- 
nara, M. S. Park, R. Tonai, P. I. Terasaki, and S. Ferrone. 1988. Anti-HLA-B7, B27, Bw42, Bw54, Bw55, Bw56, Bw67, Bw73 monoclonal antibodies: specificity, idiotypes, and application for a double determinant immunoassay. Hum. Immunol. 21:193-207.

19. Temponi, M., T. Kageshita, F. Perosa, R. Ono, H. Okada, and S. Ferrone. 1989. Purification of murine IgG monoclonal antibodies by precipitation with caprylic acid: comparison with other methods of purification. Hybridoma. 8:85-95.

20. Laemmli, U. K. 1970. Cleavage of structural proteins during the assembly of the head of bacteriophage T4. Nature (Lond.). 227:680-685.

21. Greenwood, F. C., W. M. Hunter, and J. S. Glover. 1963. The preparation of ${ }^{131}$ I-labelled human growth hormone of high specific radioactivity. Biochem. J. 89:114-123.

22. Fraker, P. J., and J. C. Speck, Jr. 1978. Protein and cell membrane iodinations with a sparingly soluble chloroamide, 1,3,4,6-tetrachloro-3a, 6a-diphenylglycoluril. Biochem. Biophys. Res. Commun. 80:849-857.

23. Perosa, F., T. Kageshita, R. Ono, and S. Ferrone. 1989. Comparison of serological methods to detect anti-idiotypic antibodies. Methods Enzymol. 178:74-90.

24. Zweig, S. E., and E. M. Shevach. 1983. Production and properties of monoclonal antibodies to guinea pig la antigens. Methods Enzymol. 92:66-85.

25. Schroff, R. W., K. A. Foon, S. M. Beatty, R. K. Oldham, and A. C. Morgan, Jr. 1985. Human anti-murine immunoglobulin response in patients receiving monoclonal antibody therapy. Cancer Res. 45:879-885.

26. Shawler, D. L., R. M. Bartholomew, L. M. Smith, and R. O. Dillman. 1985. Human immune response to multiple injections of murine monoclonal IgG. J. Immunol. 135:1530-1535.

27. Courtenay-Luck, N. S., A. A. Epenetos, R. Moore, M. Larche, D. Pectasides, B. Dhokia, and M. A. Ritter. 1986. Development of primary and secondary immune responses to mouse monoclonal antibodies used in the diagnosis and therapy of malignant neoplasms. Cancer Res. 46:6489-6493.
28. Thompson, R. J., A. P. Jackson, and N. Langlois. 1986. Circulating antibodies to mouse monoclonal immunoglobulins in normal subjects-Incidence, species specificity, and effects on a two-site assay for creatine kinase-MB isoenzyme. Clin. Chem. 32:476-481.

29. Herlyn, D., M. Wettendorff, E. Schmoll, D. Iliopoulos, J. Schedel, U. Dreikhausen, R. Raab, H. H. Ross, H. Jaksche, M. Scriba, and H. Koprowski. 1987. Anti-idiotype immunization of cancer patients: modulation of the immune response. Proc. Natl. Acad. Sci. USA. 84:8055-8059.

30. Miller, R. A., D. G. Maloney, R. Warnke, and R. Levy. 1982. Treatment of B-cell lymphoma with monoclonal anti-idiotype antibody. N. Engl. J. Med. 306:517-522.

31. Meeker, T., J. Lowder, M. L. Cleary, S. Stewart, R. Warnke, J. Sklar, and R. Levy. 1985. Emergence of idiotype variants during treatment of B-cell lymphoma with anti-idiotype antibodies. $N$. Engl. J. Med. 312:1658-1665.

32. Claflin, J. L., and J. M. Davie. 1974. Clonal nature of the immune response to phosphorylcholine. IV. Idiotypic uniformity of binding site-associated antigenic determinants among mouse antiphosphorylcholine antibodies. J. Exp. Med. 140:673-686.

33. Karol, R. A., M. Reichlin, and R. W. Noble. 1977. Evolution of an idiotypic determinant: Anti-val. J. Exp. Med. 146:435-444.

34. Ju, S. T., B. Benacerraf, and M. E. Dorf. 1978. Idiotypic analysis of antibodies to poly $\left(\mathrm{Glu}^{60} \mathrm{Ala}^{30} \mathrm{Tyr}^{10}\right)$ : Interstrain and interspecies idiotypic crossreactions. Proc. Natl. Acad. Sci. USA. 75:6192-6196.

35. Ju, S. T., D. V. Cramer, and M. E. Dorf. 1979. Idiotypic analysis of anti-gat antibodies. V. Distribution of an interspecies cross-reactive idiotype. J. Immunol. 123:877-883.

36. Kennedy, R. C., I. Ionescu-Matiu, Y. Sanchez, and G. R. Dreesman. 1983. Detection of interspecies idiotypic cross-reactions associated with antibodies to hepatitis B surfact antigen. Eur. J. Immunol. 13:232-235.

37. Hellstrom, K. E., and I. Hellstrom. 1969. Cellular immunity against tumor specific antigens. Adv. Cancer Res. 12:167-223. 